\title{
Local Government Leadership, Wealth Creation and Poverty Reduction in Nigeria
}

\author{
Professor Okoli, F.C. PhD \\ Izueke, Edwin M, Ph.D \\ email:eddyizuks@yahoo.com \\ \& Nzekwe, F.I. email:nzekwe_ify@unn.edu.ng \\ Department of Public Administration \\ And Local Government \\ University of Nigeria, Nsukka.
}

\begin{abstract}
The paper is an exploration of the roles of local government leadership in wealth creation and poverty reduction. The study was motivated by the strategic position of local government as the closest tier of government to the people. This position was seen as the most vantage to create wealth and reduce poverty in Nigeria. Effective local government leadership was explored and seen to be a stateman with resolute will and spirit as well as consistency to turn the fortunes of the people around. This is against a demagogue who is interested only in personal aggrandizement. We examined the primacy of agriculture in wealth creation and poverty reduction and found that if local government leadership can take the lead in agriculture through modernization and diversification of agricultural production enormous wealth would be created and poverty drastically reduced. The leader of the local government leadership should never be at the neglect of the people. The people should be supported and assisted. This will remove more people from the farm but still improve the value of agricultural produce in the economy.
\end{abstract}

Key words: poverty reduction, wealth creation, stateman, local government leadership, demagogue

\section{Introduction}

Nigeria is in many ways a promising nation, with a rich cultural heritage and abundant human and material resources. However, Nigeria ranks 158 out of 177 on the Human Development Index (HDR, 2008). This implies that majority of the country's 140 million (2006 census) citizens live below the poverty line and have limited or no access to basic amenities such as education, water, affordable health care facilities, security and access to sustainable sources of livelihood.

This is a paradox, given the abundant human and natural resources endowment of the country. Poverty still remains one of the greatest challenges facing the world today, in particular Africa. It remains an adversary that no one could afford to ignore or underrate (Balogun, 2004). It is imperative that poverty eradication or better reduction is tackled more proactively and innovatively in the medium and long-term through wealth creation.

Achebe (1983) strongly believes that the problem with Nigeria is leadership. It is an effective leadership, a stateman with vision and commitment would transform the abundant resources to achieve meaningful development, create wealth and reduce poverty.

Balogun (2004) contends that it is for African governments (at all levels) to provide unequivocal leadership in replacing the poverty alleviation preoccupation with the wealth- 
creation psyche. Effective leadership is required in all the tiers of government and public organizations to transform our resources into more wealth.

Strong, local authority leadership, both in urban and rural areas are crucial in ensuring effective strategies for wealth creation and poverty reduction. Today effective leadership in the local government sector requires different skills and perspective than those required by operational leadership. Leaders now need to be broad in scope, future focused and change oriented, and in all statesmen.

The paper is on how a functional leadership, a statesman can harness the potentials of local government area to create wealth and reduce poverty.

\section{The Problem}

The challenge of this paper is to examine the trajectory and functional relationship among Local Government Leadership, Wealth Creation and Poverty reduction in the context of the overall rationale for the existence of local governments in Nigeria.

\section{Objectives of the Paper}

The broad objective of the paper is to ascertain the appropriate Role of Local Government Leadership in mediating between Wealth creation and Poverty reduction in a local government area. However, the specific objectives of the paper are to:

1. Find out the extent to which Local Government Leadership is aware of the developmental problems of the local government, especially through appropriate situation analysis of the local government area.

2. Ascertain how the personality of the local government Leadership impacts on the threefactor variables of Leadership Style, Awareness or Cognition and Environment.

3. To examine how the leadership style of the local government leadership promotes or hinders development efforts in the local government area.

4. To assess the impact of Environment on the local government leadership in development efforts in the local government.

\section{Conceptual Clarifications}

\section{Leadership}

Leadership in an organization is the process of influencing the activities of an organized group in its efforts towards target achievement Ugwuegbu, (1992) quoted in Aluko(2010). It involves influencing people to exert more effort in some tasks or to change group member's behaviour. Leadership is influencing people to participate actively in the group's activities.

Leadership position is a designated position of authority in an organizational chart. For example, the position of a local government chairman is a leadership position. The occupant of such a position is perceived as a leader and he or she is expected to exercise the authority (leadership roles) associated with each position.

Local government, like any other organization is arranged in a hierarchical order with the chairman occupying the topmost position. However, the chairman delegates the leadership roles 
to the heads of the departments and committees. The Finance and General Purpose Committee is a mandatory committee following the 1976 reorganization of local governments (Yahaya, 1981). The major leadership role of this committee is to formulate policies, plans and programmes for the approval of local government council. Effective leadership is leadership with vision, that is flexible and outcome focused, and statesmanlike.

\section{Wealth Creation}

The concept of 'wealth' varies among societies. Therefore, the word wealth means different things to different people. In its most narrow sense, wealth refers to abundance of anything. According to Dada (2005) wealth refers to abundant possession of objects of value. (e.g. gold, clay, water, property, certain skills, money etc) and the state of having accumulated these objects.

The Webster Dictionary of English sees wealth among others as: natural resources of a country, whether or not exploited, the product of the economic activity of a nation; anything which can be exchanged for money or barter. It follows then that local government wealth include its natural resources, product of economic activity and anything that can be bought (health, education, skill, house, water, electricity, etc).

Smith (1976) sees wealth creation as the combination of materials, labour, land and technology in such a way as to capture profit and not financial wealth (well-being). The IMF (2003) assert that wealth creation can be narrowly defined in terms of income generation or more broadly as creation of assets, both in terms of physical and human capital. Brubarer (2003) stated that wealth creation in simple terms refers to economic growth and better standard of living for the individual, family local governments or states.

Wealth, therefore, is the possession and combination of materials, labour and technology to make profit in abundance. It is also the possession of these items in abundance.

From the foregoing wealth can be created through several means such as:

- Materials can be changed into something more valuable through proper application of labour and equipment.

- Better methods also create additional wealth by allowing faster creation of wealth.

- Gaining access to productive assets such as land, finance etc.

- Making localities attractive for investment.

- Empowerment of the people.

In summary, any wealth creation initiative must increase the productivity of the individual and family. It must boost the human capital elements such as knowledge, skills and health, which increases the total productivity of the individual and the human development index.

\section{Poverty Reduction}

Poverty describes a wide range of circumstances associated with need, hardship and lack of resources. It is a relative term depicting deprivations, which result from improper or unbalanced distribution of resources Okeke (2001). The deprivation could be of essential goods and services or a lack of wealth (usually understood as capital, money, material goods and resources). 
Poverty alleviation means making poverty more bearable. It serves as a pain reliever. However, poverty reduction means making poverty less prevalent (Ike, 2010). It means removal of the causes of the pain. Many past regimes pursued poverty alleviation programmes at the utter neglect of poverty reduction. This is giving a man fish-in-order for him to survive. This is because policy initiators viewed poverty simply as deprivation of essential goods and services. Thus attacking it, the attention of government had focused on helping the materially deprived (the poor) to alleviate his/her condition. We do not condemn alleviation but reduction would be more sustainable measure to fight poverty.

From the foregoing, it becomes imperative that to reduce poverty, wealth has to be created. Wealth creation is all encompassing, and should be for every home, family community and every local government. Mofuoa (2005) stressed that successful poverty reduction requires sustained wealth creation.

\section{Assumptions of the Paper}

The paper assumes that the rationale for local government lies in the ministering to the welfare of the grassroots, through the provision of basic amenities and other necessities of life. In other words, local government exists to bring government nearer to the people at the grassroots, thereby enabling them to benefit maximally from the dividends of good governance.

Secondly, it is the assumption of the paper that all these expectations can only come to fruition through the instrumentality of effective local government leadership.

Thirdly, and flowing from the second assumption, is the one that ascribes to the local government leadership the status and characterization of statesmanship.

In other words, it is assumed that effective local government leadership should be a statesman, and not a demagogue.

A Statesman: A statesman devotes all his mental and physical energies to the cause of the state, and its citizens (in this instant case, the local government and its population) even to the detriment of his personal convenience. In other words, a statesman is that politician who loves his country and who, in the words of the late president of the United States of America, John F.Kennedy, asks not what America can do for him but what he can do for America. A statesman is ready and willing to lay down his life in the service of his state. He elevates the interests of his country to a point of reverence and purses them with all his vigour and earnestness of purpose. He bases all his actions on the laws of the land- the constitution which he has sworn to uphold. He applies the laws of the land impartially and abides by their dictates.

The Demagogue: The demagogue, on the other hand, uses all skills, cunning, and intrigue in his power to manipulate political power. He fans the embers of ethnicism when it suits his purpose and condemns it when it no longer serves his ends. He resorts to religion when he thinks that he can gain from it and withdraws when he feels he can do without it. He invokes the rights of states-stateism- when he knows that he can gain there from, but repudiates them when doing so is likely to improve his image. He always plays to the gallery and makes promises he has no intention of fulfilling. At the slightest opportunity, he collaborates with 
the enemies to defraud the state and its people. He inflates contracts and authorizes the payment of vouchers for services not rendered. He shirks responsibilities and blames his subordinates for his failure but quickly takes the credit when his subordinates perform satisfactorily. He perverts his high office in his inglorious pursuit of his personal aggrandizement. As far as the demagogue is concerned, the end justifies the means. He has no respect for the citizens of the state and he treats them as cannon fodders. He disregards the laws of the land when they do not serve his selfish purpose. He stretches the constitution and invokes the emergency powers of the state to cow his, opponents. He flouts the constitution of the land with a bewildering careless abandon. A demagogue glories in political power for its own sake and for his personal interests.

\section{Theoretical Framework of Analysis}

For the purpose of this paper, we shall adopt and adapt James. D. Thomson's "components of purposive action in explaining the local government leadership. According to Thompson, human action emerges from the interaction of:

(i) The individual, who brings aspirations, standards, and knowledge or belief about causation, and

(ii) The situation, which presents opportunities and constraints. He further posits that the interaction of the individual and the situation is mediated by his perceptions or cognitions. Schematically, this can be represented thus in figure 1.

Fig. 1. The individual's aspirations, standards, and knowledge or belief about causation.

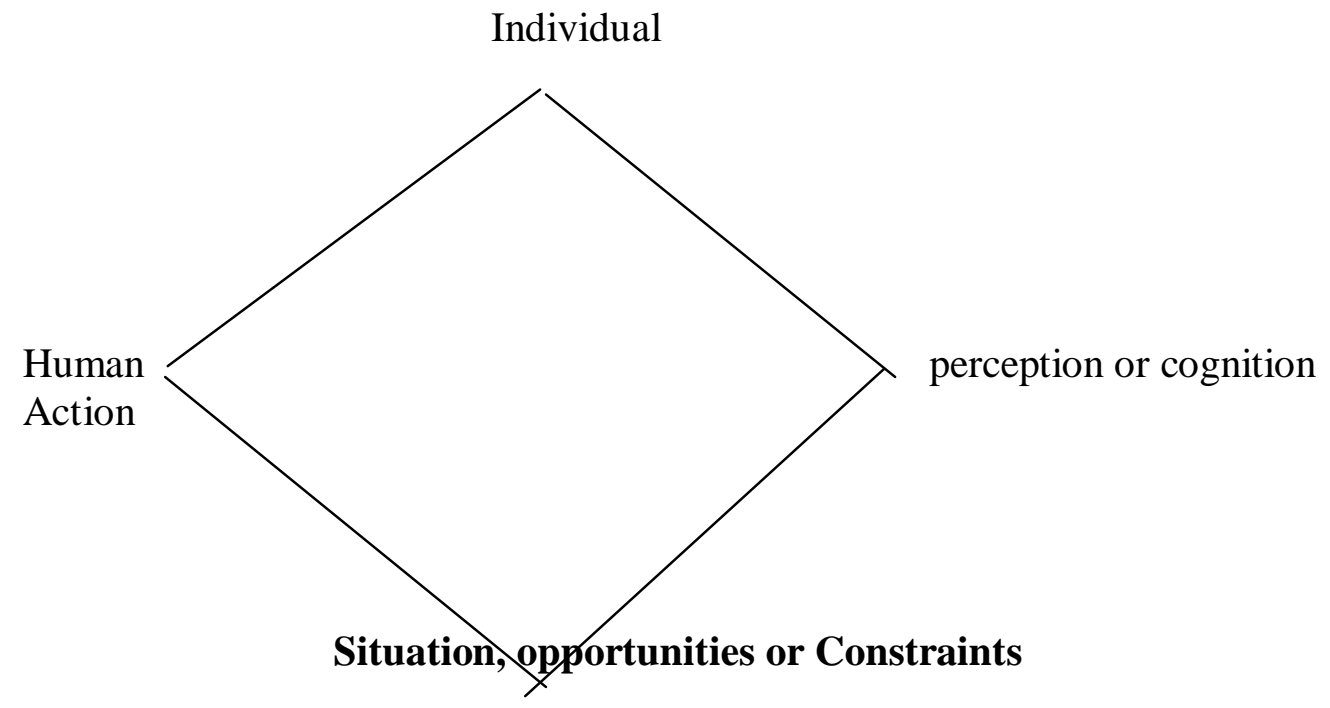

In this endeavour, the individual is guided, by his be beliefs about causation and by the standards or norms he believes are appropriate. We shall modify Thompson's formulation by substituting ENVIRONMENT for situation, PERSONALITY for individual, and Leadership style for human action. This adaptation is represented in Figure 2. 
Figure 2: Modified Components of Purposive Action

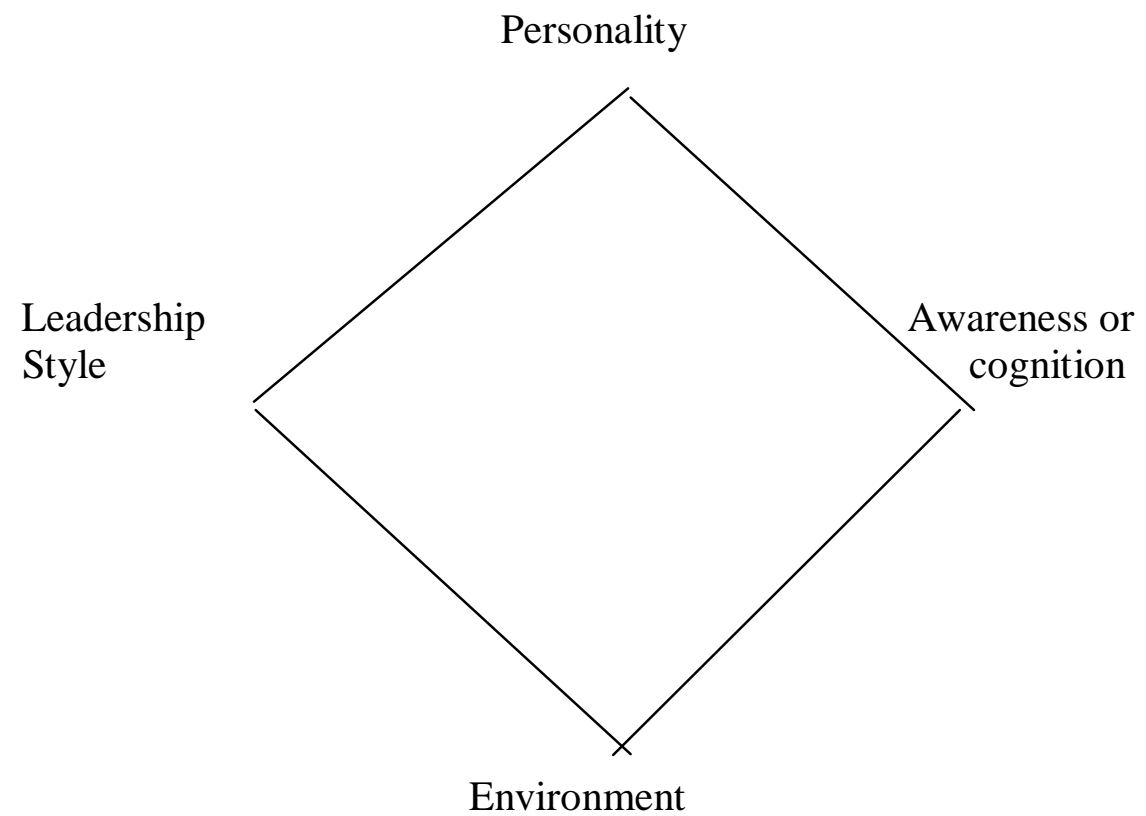

This modification is necessary because Thompson's immediate concern is with the study of organizations whereas we are studying individuals in leadership positions. Moreover, by emphasizing the interaction among the four variables - leadership style, personality, environment and awareness - we are in a position not only to search in two directions, in the individual and his environment as Thompson did, but also in his awareness of his environment and leadership style as influenced by his personality traits or potentials.

\section{An Important Caveat}

Since this study is essentially theoretical and exploratory in nature and, especially since it is not local government area specific, that is, it is not focused on any particular local government Area, the discussions on the four variables will be primarily theoretical in approach without reference to any specific individual local government leader. Consequently, we shall collapse the four- factor variables into the desirable traits and quintessence of a good leadership- the statesman.

\section{Local Government Leadership, Wealth Creation and Poverty Reduction}

For the purpose of this paper, local government leadership is the Executive Chairman, assisted by the Finance and General Purposes Committee (FGP \& C). Each head of department is among the local government leadership. The basic assumption of this paper is that the local government leadership is likened to a statesman, whose major concern is the welfare of his people, and not a demagogue, whose main interest is self-aggrandizement. More importantly, the 
paper assumes that the local government leadership should exhibit qualities of the philosopher king, who like a Doctor is in a position to correctly diagnose the ailments of his patients. The local government leadership should be able to identify and analyze the developmental challenges confronting his people and local government area. In this instant case, the challenges of wealth creation and poverty reduction.

The starting point by a good local government leadership is to identify and appreciate the major development challenges in his local government Area.

These will include:

(i) The location and size of the local government area.

(ii) The year the local government was created, and its chairman elected.

(iii) Current political setting (whether Democracy, military, etc.)

(iv) The capital / headquarters of the local government Area.

(v) Number of villages/ Development areas/centres.

(vi) Population and date of the last census

(vii) Health Maters/ indicators

(a) Life expectancy at birth for Males and Females.

(b) Percentage of the population with access to safe drinking water

(c) Percentage of the population provided with health services

(d) Rate of infant mortality

(e) Rate of Maternal Mortality

(f) Types of communicable and non-communicable diseases.

(vix) Education Matters/ indicators

(a) Percentage of age groups enrolled in primary, secondary and tertiary education

(b) Percentage of the population enrolled in vocational institutions

(c) Adult literacy Rate (male and Female).

(x) Gender comparisons in health, Education and Employment.

(xi) Economy Matters/ indicators

(a) Type: Agriculture (Commerce and industry)

(b) Size

(c) Major Problems to Growth.

\section{The Primacy of Agriculture in the Challenge of Wealth Creation and Poverty Reduction}

Local government leadership should be guided by the revelations of the minister of agriculture that between 2007 and 2010, Nigeria spent N 98 trillion on food importations. In 2010 alone, it spent N 635 billion on importation of wheat; N 356 billion on rice which amounts to spending about $\mathrm{N} 1$ billion per day on rice, N 217 billion on sugar imports as well as N 97 billion on fish importation inspite of all the marine resources, rivers, lakes, and creek that the country is blessed with. Nigeria produces 45 million metric tons (MT) of cassava, which makes her the largest producer in the world, yet the country accounts for zero percent of global value added. But Thailand which produces 10 per cent of the of the global production accounts for 80 percent of values added. What can account for this abysmal performance by Nigeria? First, 
farmers cannot get access to cassava planting material. Second, yields of cassava are still low compared to other counties. Third, cassava-processing capacity is low. Fourth, poor roads leave many farmers with losses. But nowhere is the issue of losses greater than in the case of fruits (tomatoes, mangoes, cashew, oranges). Lack of storage facilities for all-year-round preservation and consumption of fruits has led to great losses of agricultural produce.

A good local government leadership should explore and invest in Agricultural activities to confront the problem of wealth creation and poverty reduction head-long.

\section{Possible Areas in Agro-Allied Industries/ Investments for Local Government Leadership Intervention}

1. Cassava processing industries hold great promises in almost all rural local governments in Nigeria. Cassava, apart from being one of the commonest staple foods in Nigeria, is accessible to almost all rural people. More importantly, Cassava cultivation occupies a pride of place in the women economic activities, because in some parts of Nigeria, cassava cultivation is regarded as women business. Therefore, an enlightened local government leadership who focuses attention on and promotes cassava-processing industries will be empowering women economically and thereby reducing poverty among the rural dwellers.

2. Maize production and processing. This is another area where rural women dominate. Unfortunately in most parts of Nigeria, Maize production is seasonal as its cultivation depends on availability of rainfall. Although the federal government in partnership with the World Bank is experimenting on fadama programmes, the quantity from this source is still limited. However, the greatest challenge to maize and other grain production in Nigeria is inadequacy and, in some areas, absence of silos and other storage facilities to preserve crops, during bumper harvest.

3. The promotion of appropriate technologies drawing largely on local expertise, for the enhancement of production, storage, preservation and other processes.

4. Provision of training opportunities for skill acquisition as a basis for enhancing employment and income.

5. Guaranteeing the access of the poor, especially women to land, credit, information, technology, and other productive resources.

6. Education of the poor through formal and informal channels to raise their level of literacy and help them understand their rights and civic responsibilities as full citizens.

7. Building the capacity of grassroots organizations for the effective mobilization of their communities to participate in the initiation, design, implementation and management of community projects.

8. Encouragement of projects geared towards environmental protection and effective management of national resources.

9. Promotion of the effective representation of the poor in all organs and institutions that affect their welfare and interests.

10. Identifying and partnering with institutions/organizations that are pro-poor, and which fund poverty reduction interventions.

11. By far, the most urgent and critical intervention by the local government leadership is in the area of COLD STORAGE. A trip from Makurdi through Nsukka to Abakaliki during 
the peak period of fruit harvest would reveal huge and culpable losses of fruits due essentially to absences of cold storage systems. Were these fruits to be fully harvested and stored, Nigerians would be feeding on them all-the year round. This is particularly important for rural women who scavenge the bush for wild fruits and could make a living out of such an activity.

12. Other areas include Snail farming: The attraction in snail farming lies in the facts that it is easy, cheap and the returns are fast and guaranteed. Inputs are easily available and space is not a problem at all, even staff for supervision and tendering is not a problem. Snail cultivation is not only a plus in wealth creation, it also guarantees balanced diet.

13. Grass cutter cultivation. A gain, this is a very lucrative venture. A visit to many Urban and indeed rural centres, will reveal many joints where grass cutter meat is a delicacy. Apart from creating wealth, it also provides employment for those who process and serve it in these joints.

14. Fish cultivation: This is another investment that can easily be made. The imputs are easily available and returns on investment are high and sustainable. Point-and -Kill has become very popular in Urban centres where stress-ridden workers, businessmen and couples go to release tension and re-load for the next day's challenges.

15. Poultry farming is an activity, which fits the rural areas and the urban centres. It requires less capital to operate and it does not require too much space and attention. The materials for poultry farming are readily available and technical expertise is accessible.

16. Live -Stock rearing (pigs, goats, sheep, rabbits, etc) is another investment that is not too capital intensive. Moreover, demands for meat is on the increase and protein intake of the people will be guaranteed

\section{The Role of Local Government Leadership}

It is important to stress the point that the role of local government leadership in all these activities is mediated by the functions and powers of the local government as clearly enshrined in schedule four and section seven of the 1999 Nigerian constitution. The goal of the local government leadership intervention should ideally be to remove more and more people (youths and women) from the farm, but at the same time increase the value of agricultural produce in the economy. In other words, the role of the local government leadership is to revolutionize, modernize and diversify agricultural practices and production. Consequently, and very critically, the government's role will be to support and subsidize production. We suggest that each government should have a farm to take the lead while assisting the people. The implication is that government should assist in areas of fertilizer production and the facilitation of agro-allied industries, e.t.c.

\section{Conclusion}

In conclusion, the paper argues that the local government leadership holds the key to wealth creation and poverty reduction in the rural areas. But this is if and only if he is a statesman, a philosopher king and not a demagogue. This requires a resolute will and spirit as well as sustaining practices. Through appropriate and effective situation analysis of the local government area, the local government leadership can easily and correctly identify development challenges 
and their relevant sectors and prescribe appropriate developmental and investment interventions. The paper has identified such areas where intervention could be fruitful and rewarding. The paper concluded by advising that the goal of local government leadership intervention should be to take more and more people away from the farm but at the same time, increase the value of agricultural produce in the economy. It can achieve this feat by supporting and subsidizing production (and not consumption) by funding research and modernizing agricultural inputs and practices. This is the only sure route to wealth creation and poverty reduction in the local government area.

\section{References}

Achebe C (1983) The trouble with Nigeria: Enugu: Fourth Dimension Publishing Co. Ltd.

Alawode O (2011) How Poultry Farmers can ensure greater Productivity. Businessday, Wednesday 20 July, P. 28

Aluko, J (2010) Anti-corruption: Leadership? Followership Dimension and its implication for National Development.

Balogun, M.J (2004) "'The role of Public Administration in wealth creation" $25^{\text {th }}$ AAPAM annual Conference on the role of Public service in Poverty Reduction Strategies: Challenges and Solutions, Banjul, Gambia,19-23 April

Brubarer, K.P (2003) "Wealth creation, poverty reduction and social justice: A world council of churches perspectives" International conference on religion and globalization, JulyAugust.

Dada J O (2005).Wealth creation versus poverty alleviation: A definitive crisis?

Paper presented to the African Association for Public Administration and Management on the $26^{\text {th }}$ AAPAM annual conference held at Whitesands Hotel Mombasa, Kenya

Editorial (2011) Nigeria's poverty is a choice. Businessday, 20 July P.12.

Federal Republic of Nigeria (1976), Guidelines for Local Government Reform. Kaduna: Government Printer.

Iheduru OC (2011) CBN must end its agricultural loan racket now. Businessday, Thursday 21 July p.44.

Ike S (2010) Wealth creation versus poverty reduction. Philippine Community Newspaper. 24 December. 
Kets de Vries M (2011) Putting leaders on the couch The Harvard Business Review, New York: New York Times syndicate.

Lawson S (2011) You can boost your agribusiness through internet. Businessday Wednesday 20, July p.39.

Lieberman S (2011) Three-dimensional leadership development. The Harvard Business Review Series in Businessday, Wednesday 23 March, P.37

Mufuoa, K.V. (2005) "Poverty Reduction Through Wealth Creation: A Business Ethics Approach". A Paper Presented by African Association for Public Administration and Management: Witesands Hotels, Mombasa Kenya, $7^{\text {th }}-11^{\text {th }}$ March.

Nuhu-koko A (2010) “1PPs, PPPs and concessioning: Nigeria's new honey pots? Businessday, Friday 16-Sunday 18, July, P.11.

Nwachukwu I (2011) Businessday Wednesday 20 July, P. 23.

Obozuwa, D. (2010) PPP as a tool for infrastructure development in Nigeria Businessday, Thursday 14, October P. 33.

Okiti, Oguo (2010) "How Jonathan Can create Jobs in their millions -Agriculture” Businessday, Monday 18 July P.58.

Ozioma, Unegbu (2010) "Addressing Youth Unemployment in Nigeria.” Business Day Thursday 14 October, P.14.

Siaka, Momoh (2011) "Putting People first” Business Day, Monday, 18 July, P.35.

Siaka, Momoh (2011) “Small Enterprises and funding Issues” Businessday Monday 21 March, p. 29.

Smith, A. (1976) The Wealth of Nations (ed) R.H. Campbell and A.S. Skinner, The Glassgow Edition of the Works and Correspondence of Adam Smith Vol. 2a Oxford: Claredon Press.

Tunji, Afuwape (2011) "How to tap into foodstuff Export market" Businessday, Monday $18^{\text {th }}$ July P.36.

Ubosi, S. Chucdi (2010) "The N 150 billion industrial intervention fund and issues thereof" Businessday, Friday 16- Sunday 18 July, P. 12

Yahaya, A.D. (1981) "Local Government in Nigeria: The 1976 Reorganization", in Oyeleye Oyediranm ed., Survey of Nigerian Affairs 1976-1977. Lagos: Nigerian Institute of International Affairs 